\title{
Protonless NMR experiments for sequence-specific assignment of backbone nuclei in unfolded proteins
}

\author{
Wolfgang Bermel ${ }^{1}$, Ivano Bertini ${ }^{2, *}$, Isabella C. Felli ${ }^{2}$, Yong-Min Lee ${ }^{2}$, Claudio Luchinat ${ }^{3}$, \\ and Roberta Pierattelli ${ }^{2}$
}

${ }^{1}$ Bruker BioSpin GmbH, Rheinstetten, Germany;

${ }^{2}$ CERM and Department of Chemistry, University of Florence, Italy;

${ }^{3}$ CERM and Department of Agricultural Biotechnology, University of Florence, Italy.

\section{Supporting Information}


The NMR experiments described in detail here below were recorded at $288 \mathrm{~K}$ on a $16.4 \mathrm{~T}$ Bruker Avance 700 NMR spectrometer operating at $700.06 \mathrm{MHz}$ for ${ }^{1} \mathrm{H}$ and $176.03 \mathrm{MHz}$ for ${ }^{13} \mathrm{C}$, equipped with a room-temperature TXO probe-head optimized for ${ }^{13} \mathrm{C}$-observation.

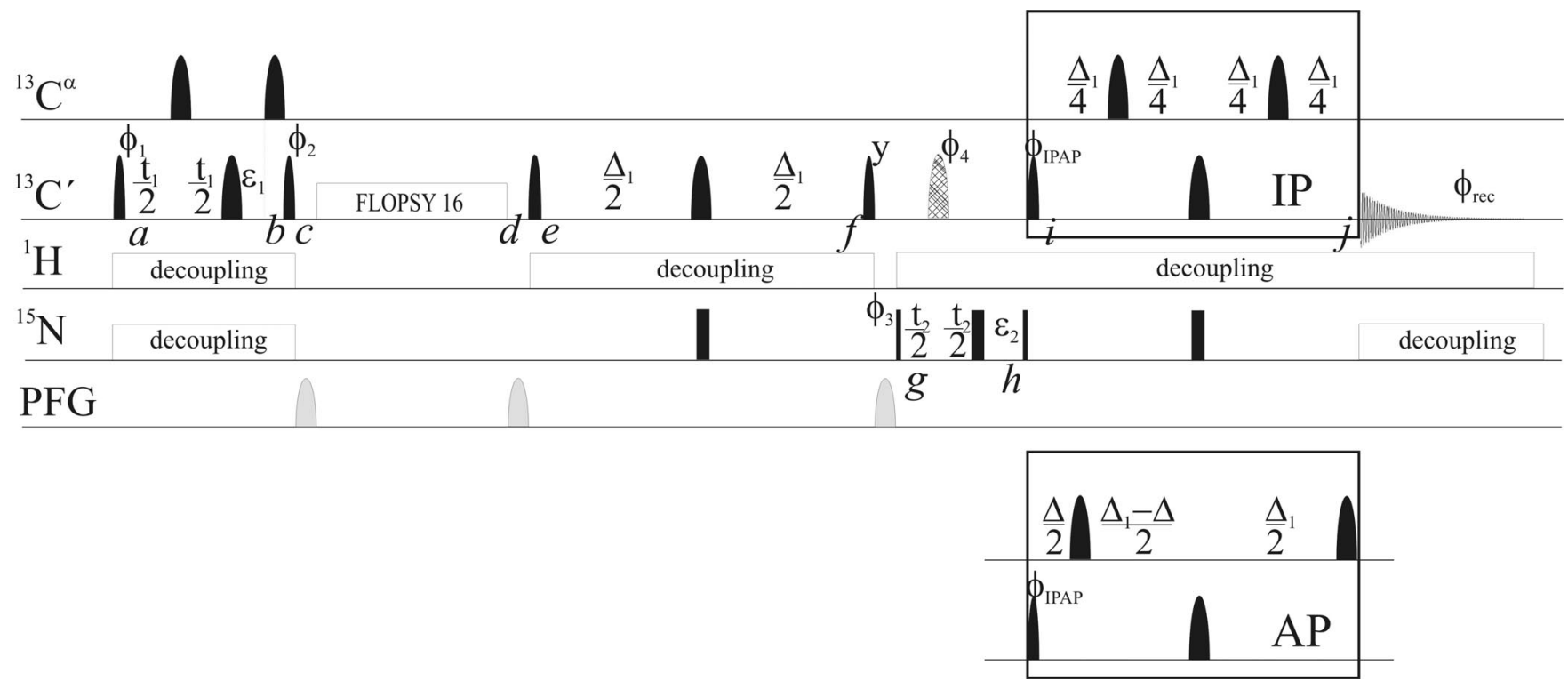

Figure SI1. Pulse scheme used to acquire the 3D COCON-IPAP experiment and experimental parameters

\section{Description of the pulse sequence}

The $\mathrm{C}_{\mathrm{i}}^{\prime}$ transverse magnetization created at time point $a$ is frequency labeled during $\mathrm{t}_{1}\left(a-b\right.$, the $\mathrm{C}^{\prime}-\mathrm{C}^{\alpha}$, $\mathrm{C}^{\prime}-\mathrm{C}^{\beta}, \mathrm{C}^{\prime}-\mathrm{N}$ and $\mathrm{C}^{\prime}-\mathrm{H}$ scalar couplings are refocused) and then turned back to the $\mathrm{z}$ axis $(c)$ before the spin-lock. The spin $\operatorname{lock}^{1}(c-d)$ is applied with a weak RF power for a time long enough to allow evolution of small ${ }^{3} \mathrm{~J}_{\mathrm{C}^{\prime} \mathrm{C}^{\prime}}$ scalar couplings (avoiding evolution of larger $\mathrm{C}^{\prime}-\mathrm{C}^{\alpha}$, and $\mathrm{C}^{\prime}-\mathrm{C}^{\beta}$ couplings) and thus transfer magnetization to/from the neighbouring carbons $\left(\mathrm{C}_{\mathrm{i}-1}^{\prime}, \mathrm{C}_{\mathrm{i}+1}^{\prime}\right)$. This building block has already been proposed independently by $\operatorname{Bax}^{1}$ and later by Wüthrich ${ }^{2}$, embedded in ${ }^{1} \mathrm{H}$ detected triple resonance experiments. The $\pi / 2 \mathrm{C}^{\prime}$ pulse then creates again transverse $\mathrm{C}_{\mathrm{i}}^{\prime}$ coherence $-\mathrm{C}_{\mathrm{iy}}^{\prime}(e)$ that evolves, under the influence of the $\mathrm{C}^{\prime}-\mathrm{N}$ one bond scalar coupling into $-2 \mathrm{C}^{\prime}{ }_{i x} \mathrm{~N}_{\mathrm{i}+1 \mathrm{z}}(f)$. The latter is transformed into $-2 \mathrm{C}^{\prime}{ }_{\text {iz }} \mathrm{N}_{\mathrm{i}+1 \mathrm{y}}(\mathrm{g})$, in order to achieve frequency labeling during $\mathrm{t}_{2}$ with the ${ }^{15} \mathrm{~N}$ chemical

\footnotetext{
${ }^{1}$ We used here the FLOPSY 16 sequence but other spin-lock schemes can be used as well.
} 
shift $(g-h)$. This is then transferred back to carbonyl magnetization in-phase with respect to nitrogen $(i$ $j$ ) and acquired $\left(t_{3}\right)$. In order to suppress the $C^{\prime}-C^{\alpha}$ coupling through the IPAP approach, the two variants of the experiment that differ for the part in the boxes indicated with IP and AP are necessary. In the IP version, no evolution of the $\mathrm{C}^{\prime}-\mathrm{C}^{\alpha}$ coupling occurs from time points $i$ to $j$ (the two $\pi$ pulses on $\mathrm{C}^{\alpha}$ are only necessary to have the same number of pulses in the two variants). In the AP version the two $\pi$ pulses on $C^{\alpha}$ are shifted in order to obtain a total evolution of the $C^{\prime}-C^{\alpha}$ coupling of $9 \mathrm{~ms}\left(1 / 2 J_{C^{\prime}-\mathrm{C} \alpha}\right)$. Summarizing, the transfer pathway is $\mathrm{F} 1\left(\mathrm{C}^{\prime}, \mathrm{t}_{1}\right) \rightarrow \mathrm{F} 3\left(\mathrm{~N}, \mathrm{t}_{2}\right) \rightarrow \mathrm{F} 1\left(\mathrm{C}^{\prime}, \mathrm{t}_{3}\right)$. The backbone correlations expected are: $\mathrm{C}^{\prime}{ }_{\mathrm{i}}-\mathrm{C}_{\mathrm{i}}^{\prime}-\mathrm{N}_{\mathrm{i}+1}$ (“diagonal peak"), $\mathrm{C}_{\mathrm{i}-1}^{\prime}-\mathrm{C}_{\mathrm{i}}^{\prime}-\mathrm{N}_{\mathrm{i}+1}$ (“previous”) and $\mathrm{C}^{\prime}{ }_{\mathrm{i}+1}-\mathrm{C}^{\prime}{ }_{\mathrm{i}}-\mathrm{N}_{\mathrm{i}+1}$ ("following"). Additional correlations for Asp and Asn residues are also expected.

\section{Experimental parameters used for the 3D COCON-IPAP experiment}

Narrow and wide pulses represent $\pi / 2$ and $\pi$ pulses respectively; ${ }^{15} \mathrm{~N}$ pulses are denoted by rectangles and band selective ${ }^{13} \mathrm{C}$ pulses are denoted by shapes. For ${ }^{13} \mathrm{C}$ bandselective $\pi / 2$ and $\pi$ pulses Q5 (or time reversed Q5) and Q3 shapes ${ }^{3}$ were used with durations of $274 \mu \mathrm{s}$ and $220 \mu$ s respectively except for the $\pi$ pulse indicated in crossed stripes (adiabatic inversion pulse over the $C^{\prime}$ and $C^{\alpha}$ regions, $500 \mu$ s chirp shape with $60 \mathrm{kHz}$ sweep and 25\% smoothing). ${ }^{4}$ Pulse field gradients (PFG line) are indicated by grey shapes. All the gradients are used for purging and not for coherence selection and have a duration of 1.0 ms and a sine-shape. The ${ }^{1} \mathrm{H}$ and ${ }^{15} \mathrm{~N}$ carriers were placed at 8 and $120 \mathrm{ppm}$, respectively. The ${ }^{13} \mathrm{C}$ carrier was placed at $174 \mathrm{ppm}$; the $\mathrm{C}^{\alpha}$ pulses are centered at $52 \mathrm{ppm}$ while the adiabatic pulse at 113 ppm. The ${ }^{13} \mathrm{C}$ FLOPSY16 spin-lock was applied for $190 \mathrm{~ms}$ with RF power of $2.78 \mathrm{kHz}$. Decoupling on the ${ }^{1} \mathrm{H}$ and ${ }^{15} \mathrm{~N}$ was applied with $1.67 \mathrm{kHz}$ (waltz-16) ${ }^{5}$ and $0.625 \mathrm{kHz}$ (garp-4) ${ }^{6}$ respectively. In order to suppress the $\mathrm{C}^{\prime}-\mathrm{C}^{\alpha}$ coupling through the IPAP approach, the in-phase (IP) and anti-phase (AP) components are acquired and stored separately using the pulse schemes illustrated that differ only for the two panels indicated with IP and AP respectively. The in-phase and anti-phase components are combined to yield the two multiplet components, shifted to the centre of the original multiplet (by $J_{\mathrm{C}^{\prime} \mathrm{C} \alpha}$ $/ 2 \mathrm{~Hz}$ ) and summed to obtain a singlet. ${ }^{7 ; 8}$ The delays are: $\Delta=9 \mathrm{~ms}, \Delta_{1}=30 \mathrm{~ms}, \varepsilon_{1}=\mathrm{t}_{1}(0), \varepsilon_{2}=\mathrm{t}_{2}(0)+$ $500 \mu \mathrm{s}$, where $500 \mu \mathrm{s}$ is the duration of the $\pi$ adiabatic pulse in the middle of the $t_{2}$ evolution delay. The phase cycle is: $\phi_{1}=\mathrm{x},-\mathrm{x} ; \phi_{2}=4 \mathrm{x}, 4(-\mathrm{x}) ; \phi_{3}=2 \mathrm{x}, 2(-\mathrm{x}) ; \phi_{4}=8 \mathrm{x}, 8(-\mathrm{x}) ; \phi_{\mathrm{IPAP}}(\mathrm{IP})=\mathrm{x} ; \phi_{\mathrm{IPAP}}(\mathrm{AP})=-\mathrm{y} ; \phi_{\mathrm{rec}}=$ $\mathrm{x},(-\mathrm{x}),(-\mathrm{x}), \mathrm{x},(-\mathrm{x}), \mathrm{x}, \mathrm{x},(-\mathrm{x})$. Quadrature detection in the $\mathrm{F}_{1}$ and $\mathrm{F}_{2}$ dimension is obtained by incrementing, in a States-TPPI manner, $\phi_{1}$ and $\phi_{3}$ respectively. The experiment was acquired with a relaxation delay of $1.2 \mathrm{~s}, 16$ scans, $1024 \times 64 \times 256$ points and spectral widths of $35 \times 44 \times 17$ ppm in 
the three dimensions respectively $\left({ }^{13} \mathrm{C},{ }^{15} \mathrm{~N},{ }^{13} \mathrm{C}\right)$ for a total of about $110 \mathrm{~h}$. The data, after the preprocessing required for the IPAP approach, were multiplied by a squared cosine window function, zero filled and processed through Fourier transformation, to a matrix of $1024 \times 256 \times 512$ (linear prediction was applied in the indirect dimensions).

Experimental parameters used for the other NMR experiments (2D CON-IPAP, 3D CBCACON-IPAP)

For the 2D CON-IPAP and 3D CBCACON-IPAP the recently reported pulse schemes ${ }^{9}$ were used. The ${ }^{1} \mathrm{H}$ and ${ }^{15} \mathrm{~N}$ carriers are placed at 4.7 and $120 \mathrm{ppm}$, respectively. The bandselective ${ }^{13} \mathrm{C}$ pulses were given in the center of the $C^{\prime}, C^{\alpha}$ and $C^{\text {ali }}$ regions, respectively, with the same durations and shapes described above. The spectral widths were about $35 \mathrm{ppm}$ for $\mathrm{C}^{\prime}, 44 \mathrm{ppm}$ for $\mathrm{N}$, and $81 \mathrm{ppm}$ for $\mathrm{C}^{\text {ali }}$. Experiments were acquired with a relaxation delay of $1.2 \mathrm{~s}$ and acquisition times of about $80 \mathrm{~ms}$. The two experiments were acquired with the following number of scans and points: 2D CON-IPAP (16 scans, $1024 \times 512$ data points), 3D CBCACON-IPAP (16 scans, $1024 \times 64 \times 160$ data points), for a total of about $3 \mathrm{~h}$ and $60 \mathrm{~h}$, respectively. Treatment of the data prior to Fourier transform was performed as described for the COCON-IPAP experiment. The data were then multiplied by a squared cosine window function, zero filled and processed through Fourier transformation, to matrices of $2048 \times 1024$ for the 2D CON-IPAP, $1024 \times 256 \times 512$ for the 3D CBCACON-IPAP (linear prediction was applied in the indirect dimensions). 

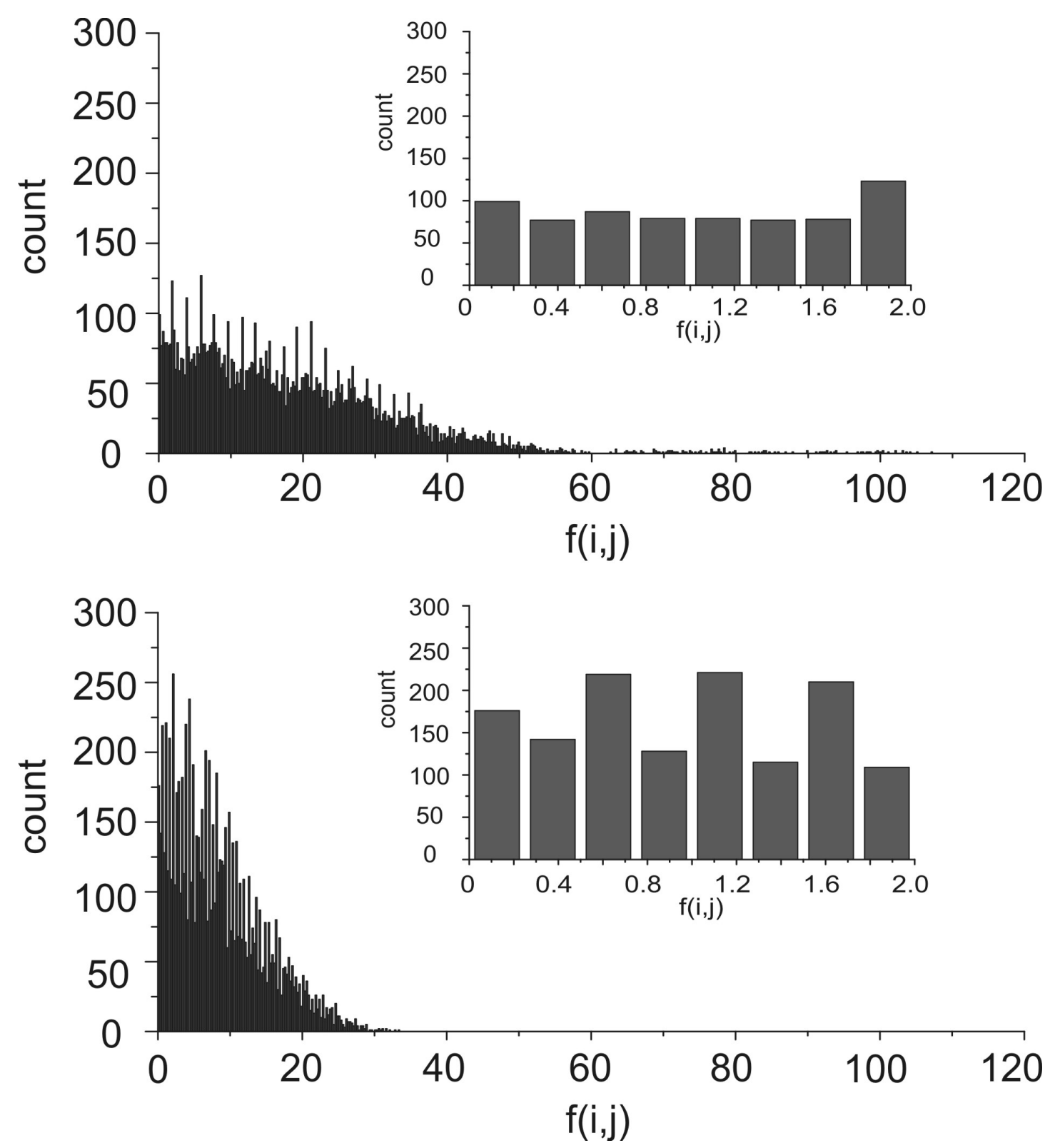

Figure SI2. The function $\mathrm{f}(\mathrm{i}, \mathrm{j})=\left|(\delta \mathrm{i}-\delta \mathrm{j}) / \Delta v_{1 / 2}\right|$, where $\delta_{\mathrm{i}}$ and $\delta \mathrm{j}$ are the chemical shifts (in $\mathrm{Hz}$ ) of two nuclei $i$ and $j$ and $\Delta v_{1 / 2}$ is their average linewidth at half height, was calculated for backbone $\mathrm{H}^{\mathrm{N}}$ protons and backbone carbonyl carbons for 133 out of 140 residues in $\alpha$-synuclein (those for which data existed for both nuclei). The average linewidths for $\mathrm{H}^{\mathrm{N}}$ and $\mathrm{C}$ ' signals were measured on the ${ }^{1} \mathrm{H}^{-15} \mathrm{~N} H S Q C$ and CON-IPAP spectra, respectively recorded at the same field and with comparable conditions. The superior dispersion in the values of this function for $\mathrm{C}^{\prime}$ with respect to $\mathrm{H}^{\mathrm{N}}$ is demonstrated in the form of a histogram. The enlargement (inset) for values of the function from zero to two shows that there are considerably more signals that are ill-resolved in the $\mathrm{H}^{\mathrm{N}}$ than in the $\mathrm{C}^{\prime}$ 'dimension. 

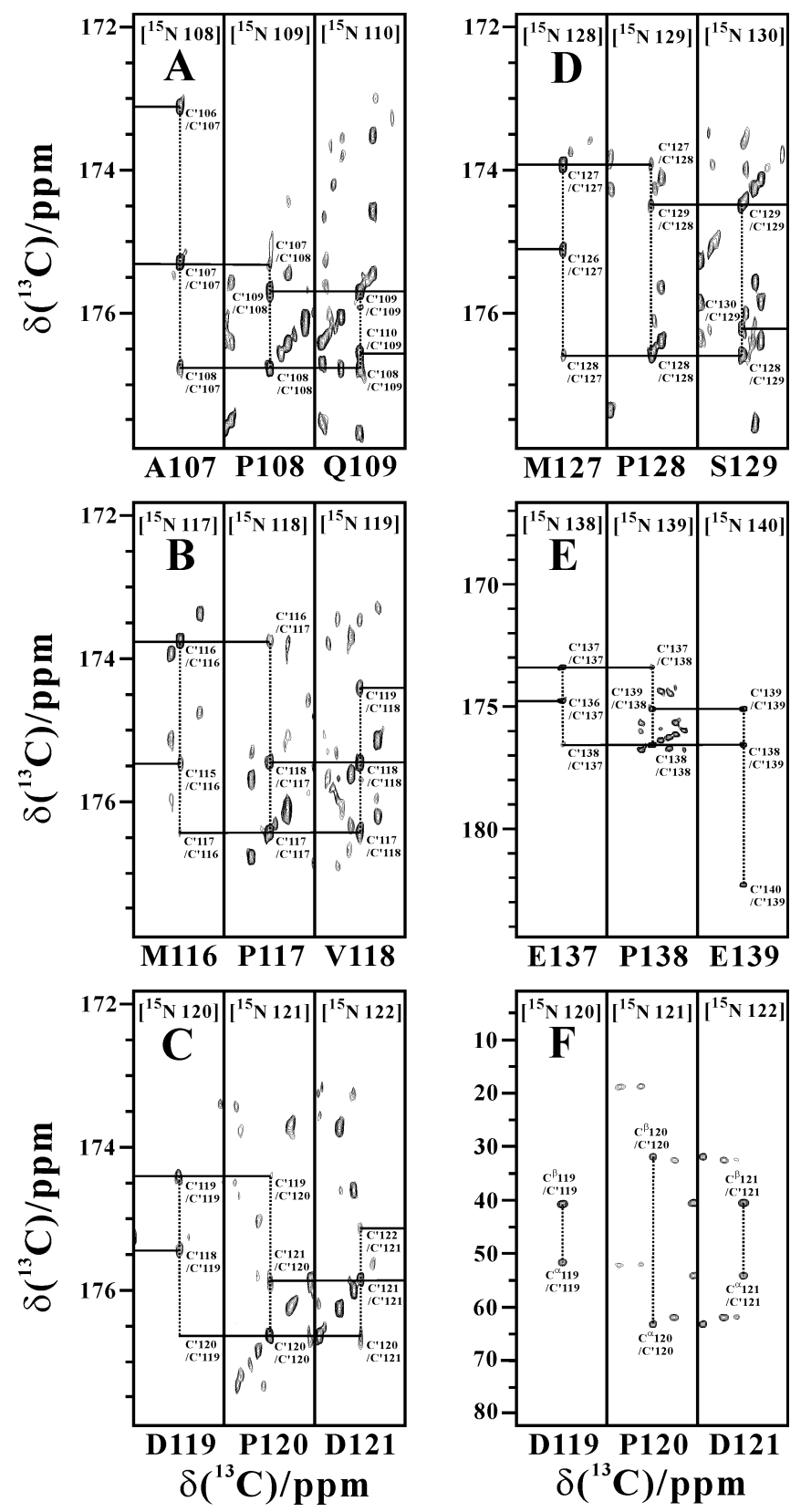

Figure SI3. Representative slices of ${ }^{13} \mathrm{C}^{\prime}-{ }^{13} \mathrm{C}^{\prime}$ planes at specific ${ }^{15} \mathrm{~N}$ resonances taken from the $16.4 \mathrm{~T}$ COCON-IPAP spectrum of ${ }^{13} \mathrm{C}-{ }^{15} \mathrm{~N}$-labelled $\alpha$-synuclein for all Pro residues (panels A-E) at $288 \mathrm{~K}$. For each residue indicated on the bottom, the three correlations necessary for sequence specific assignment

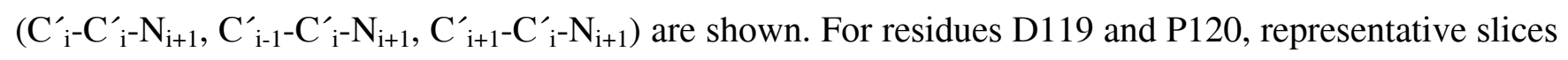
of ${ }^{13} \mathrm{C}^{\text {ali }}{ }_{-}^{13} \mathrm{C}^{\prime}$ planes at specific ${ }^{15} \mathrm{~N}$ resonances taken from the $16.4 \mathrm{~T}$ CBCACON-IPAP spectrum of ${ }^{13} \mathrm{C}_{-}{ }^{15} \mathrm{~N}$-labelled $\alpha$-synuclein are also shown (panel F) where, for each residue, the $\mathrm{C}^{\alpha}{ }_{\mathrm{i}^{-}} \mathrm{C}^{\prime}{ }_{\mathrm{i}}-\mathrm{N}_{\mathrm{i}+1}$ and $\mathrm{C}^{\beta}{ }_{\mathrm{i}^{-}}$ $\mathrm{C}^{\prime}{ }_{\mathrm{i}}-\mathrm{N}_{\mathrm{i}+1}$ correlations are present. 
Table S1. Summary of the signal assignment obtained for ${ }^{13} \mathrm{C}-{ }^{15} \mathrm{~N} \alpha$-synuclein at $288 \mathrm{~K}$ with the COCON-IPAP and CBCACON-IPAP experiments. Carbon chemical shifts were referred to external 2,2-dimethyl-2-silapentane-5-sulfonic acid (DSS), while nitrogen chemical shifts were indirectly referred to external liquid ammonia.

\begin{tabular}{|c|c|c|c|c|c|}
\hline \multicolumn{2}{|c|}{ Res. No. } & $\mathbf{N}$ & $\mathbf{C}^{\prime}$ & $\mathbf{C}^{\alpha}$ & $C^{\beta}$ \\
\hline 1 & Met & - & - & - & - \\
\hline 2 & Asp & - & 175.56 & 53.93 & 41.20 \\
\hline 3 & Val & 120.26 & 175.61 & 61.86 & 32.30 \\
\hline 4 & Phe & 123.43 & 175.54 & 57.74 & 39.00 \\
\hline 5 & Met & 122.20 & 175.66 & 55.29 & 32.34 \\
\hline 6 & Lys & 122.46 & 176.87 & 56.61 & 32.40 \\
\hline 7 & Gly & 109.75 & 173.90 & 44.89 & \\
\hline 8 & Leu & 121.38 & 177.37 & 54.79 & 42.05 \\
\hline 9 & Ser & 116.54 & 174.30 & 57.89 & 63.42 \\
\hline 10 & Lys & 123.58 & 176.18 & 55.80 & 32.44 \\
\hline 11 & Ala & 125.12 & 177.64 & 52.34 & 18.80 \\
\hline 12 & Lys & 120.71 & 176.43 & 56.29 & 32.53 \\
\hline 13 & Glu & 121.98 & 176.75 & 56.61 & 29.83 \\
\hline 14 & Gly & 110.01 & 173.75 & 44.89 & \\
\hline 15 & Val & 119.98 & 176.21 & 62.17 & 32.38 \\
\hline 16 & Val & 125.08 & 175.73 & 61.87 & 32.36 \\
\hline 17 & Ala & 128.33 & 177.40 & 52.17 & 18.75 \\
\hline 18 & Ala & 123.54 & 177.63 & 52.32 & 18.72 \\
\hline 19 & Ala & 122.92 & 177.92 & 52.38 & 18.75 \\
\hline 20 & Glu & 119.90 & 176.65 & 56.46 & 29.85 \\
\hline 21 & Lys & 122.09 & 176.87 & 56.37 & 32.54 \\
\hline 22 & Thr & 115.12 & 174.40 & 61.69 & 69.38 \\
\hline
\end{tabular}

\begin{tabular}{|c|c|c|c|c|c|}
\hline 23 & Lys & 123.61 & 176.43 & 56.33 & 32.54 \\
\hline 24 & Gln & 121.54 & 176.32 & 55.83 & 29.04 \\
\hline 25 & Gly & 110.36 & 173.98 & 44.90 & \\
\hline 26 & Val & 119.59 & 176.10 & 62.16 & 32.37 \\
\hline 27 & Ala & 127.22 & 177.86 & 52.40 & 18.66 \\
\hline 28 & Glu & 120.40 & 176.39 & 56.55 & 29.76 \\
\hline 29 & Ala & 124.76 & 177.47 & 52.21 & 18.75 \\
\hline 30 & Ala & 122.88 & 178.18 & 52.48 & 18.75 \\
\hline 31 & Gly & 107.62 & 173.92 & 44.91 & \\
\hline 32 & Lys & 120.54 & 176.73 & 55.89 & 32.76 \\
\hline 33 & Thr & 115.44 & 174.38 & 61.54 & 69.46 \\
\hline 34 & Lys & 123.68 & 176.24 & 56.30 & 32.54 \\
\hline 35 & Glu & 121.90 & 176.69 & 56.62 & 29.84 \\
\hline 36 & Gly & 109.78 & 173.72 & 44.90 & \\
\hline 37 & Val & 119.40 & 175.65 & 61.86 & 32.38 \\
\hline 38 & Leu & 125.65 & 176.37 & 54.56 & 42.01 \\
\hline 39 & Tyr & 122.27 & 175.30 & 57.41 & 38.47 \\
\hline 40 & Val & 123.16 & 175.87 & 61.78 & 32.44 \\
\hline 41 & Gly & 112.00 & 173.67 & 44.74 & \\
\hline 42 & Ser & 115.43 & 174.48 & 57.89 & 63.42 \\
\hline 43 & Lys & 123.27 & 176.59 & 56.13 & 32.68 \\
\hline 44 & Thr & 115.30 & 174.29 & 61.38 & 69.45 \\
\hline 45 & Lys & 123.67 & 176.24 & 56.26 & 32.53 \\
\hline & & & & & \\
\hline 301 &
\end{tabular}




\begin{tabular}{|c|c|c|c|c|c|}
\hline 46 & Glu & 121.82 & 176.67 & 56.36 & 30.00 \\
\hline 47 & Gly & 109.81 & 173.58 & 44.91 & \\
\hline 48 & Val & 119.74 & 175.76 & 61.85 & 32.38 \\
\hline 49 & Val & 124.87 & 175.60 & 61.84 & 32.38 \\
\hline 50 & His & 124.08 & 175.14 & 55.37 & 29.99 \\
\hline 51 & Gly & 110.42 & 173.49 & 44.74 & \\
\hline 52 & Val & 119.40 & 175.66 & 61.76 & 32.48 \\
\hline 53 & Ala & 128.05 & 177.55 & 52.13 & 18.90 \\
\hline 54 & Thr & 114.71 & 174.27 & 61.38 & 69.47 \\
\hline 55 & Val & 122.91 & 175.60 & 61.84 & 32.52 \\
\hline 56 & Ala & 127.93 & 177.51 & 52.19 & 18.81 \\
\hline 57 & Glu & 120.73 & 176.43 & 56.32 & 29.98 \\
\hline 58 & Lys & 122.66 & 176.70 & 55.99 & 32.69 \\
\hline 59 & Thr & 115.81 & 174.34 & 61.58 & 69.42 \\
\hline 60 & Lys & 123.52 & 176.40 & 56.23 & 32.54 \\
\hline 61 & Glu & 122.01 & 176.15 & 56.36 & 29.90 \\
\hline 62 & Gln & 121.62 & 175.69 & 55.41 & 29.11 \\
\hline 63 & Val & 121.81 & 176.07 & 61.95 & 32.39 \\
\hline 64 & Thr & 117.94 & 173.77 & 61.32 & 69.40 \\
\hline 65 & Asn & 121.66 & 174.97 & 52.69 & 38.57 \\
\hline 66 & Val & 120.56 & 176.59 & 62.30 & 32.06 \\
\hline 67 & Gly & 112.47 & 174.38 & 44.89 & \\
\hline 68 & Gly & 108.67 & 173.45 & 44.60 & \\
\hline 69 & Ala & 123.61 & 177.39 & 52.02 & 18.92 \\
\hline 70 & Val & 120.33 & 176.05 & 61.96 & 32.37 \\
\hline 71 & Val & 125.26 & 176.01 & 61.84 & 32.38 \\
\hline 72 & Thr & 118.48 & 174.63 & 61.40 & 69.42 \\
\hline
\end{tabular}

\begin{tabular}{|c|c|c|c|c|c|}
\hline 73 & Gly & 111.20 & 173.73 & 44.96 & \\
\hline 74 & Val & 119.33 & 176.28 & 61.91 & 32.47 \\
\hline 75 & Thr & 118.78 & 173.80 & 61.56 & 69.47 \\
\hline 76 & Ala & 127.25 & 177.29 & 52.08 & 18.95 \\
\hline 77 & Val & 119.92 & 175.74 & 61.85 & 32.38 \\
\hline 78 & Ala & 127.97 & 177.36 & 52.14 & 18.81 \\
\hline 79 & Gln & 120.21 & 175.67 & 55.41 & 29.27 \\
\hline 80 & Lys & 123.11 & 176.41 & 56.04 & 32.75 \\
\hline 81 & Thr & 116.76 & 174.15 & 61.59 & 69.51 \\
\hline 82 & Val & 122.90 & 175.87 & 61.90 & 32.44 \\
\hline 83 & Glu & 125.17 & 176.75 & 56.51 & 29.89 \\
\hline 84 & Gly & 110.55 & 173.87 & 44.94 & \\
\hline 85 & Ala & 123.79 & 178.22 & 52.56 & 18.80 \\
\hline 86 & Gly & 108.01 & 174.02 & 44.96 & \\
\hline 87 & Ser & 115.53 & 174.44 & 58.02 & 63.58 \\
\hline 88 & Ile & 122.60 & 176.00 & 60.97 & 38.29 \\
\hline 89 & Ala & 127.88 & 177.29 & 52.23 & 18.64 \\
\hline 90 & Ala & 123.17 & 177.45 & 52.26 & 18.80 \\
\hline 91 & Ala & 123.26 & 177.85 & 52.25 & 18.80 \\
\hline 92 & Thr & 112.47 & 174.88 & 61.74 & 69.52 \\
\hline 93 & Gly & 110.54 & 173.33 & 44.88 & \\
\hline 94 & Phe & 120.16 & 175.19 & 57.48 & 39.33 \\
\hline 95 & Val & 123.63 & 175.14 & 61.67 & 32.68 \\
\hline 96 & Lys & 126.28 & 176.22 & 56.04 & 32.59 \\
\hline 97 & Lys & 123.60 & 176.10 & 56.20 & 32.75 \\
\hline 98 & Asp & 121.04 & 175.94 & 54.14 & 40.67 \\
\hline 99 & GIn & 120.02 & 175.76 & 55.41 & 29.08 \\
\hline
\end{tabular}




\begin{tabular}{|c|c|c|c|c|c|}
\hline 100 & Leu & 122.68 & 177.73 & 55.09 & 41.87 \\
\hline 101 & Gly & 109.64 & 173.81 & 44.95 & \\
\hline 102 & Lys & 120.60 & 176.20 & 55.89 & 32.75 \\
\hline 103 & Asn & 119.81 & 175.01 & 53.03 & 38.45 \\
\hline 104 & Glu & 121.26 & 176.26 & 56.37 & 29.89 \\
\hline 105 & Glu & 121.97 & 176.77 & 56.53 & 29.86 \\
\hline 106 & Gly & 110.01 & 173.14 & 44.65 & \\
\hline 107 & Ala & 124.79 & 175.29 & 50.18 & 17.85 \\
\hline 108 & Pro & 135.82 & 176.78 & 62.71 & 31.65 \\
\hline 109 & Gln & 121.03 & 175.70 & 55.41 & 29.26 \\
\hline 110 & Glu & 122.39 & 176.57 & 56.36 & 30.05 \\
\hline 111 & Gly & 110.12 & 173.49 & 44.96 & \\
\hline 112 & Ile & 119.99 & 175.99 & 60.63 & 38.29 \\
\hline 113 & Leu & 126.85 & 176.88 & 54.63 & 41.96 \\
\hline 114 & Glu & 122.09 & 175.61 & 56.20 & 30.21 \\
\hline 115 & Asp & 121.26 & 175.50 & 53.98 & 40.84 \\
\hline 116 & Met & 121.83 & 173.78 & 52.87 & 32.11 \\
\hline 117 & Pro & 137.23 & 176.43 & 62.55 & 31.80 \\
\hline 118 & Val & 120.71 & 175.47 & 61.60 & 32.64 \\
\hline 119 & Asp & 125.82 & 174.43 & 51.75 & 40.81 \\
\hline 120 & Pro & 136.34 & 176.65 & 63.17 & 31.80 \\
\hline 121 & Asp & 119.09 & 175.89 & 54.16 & 40.53 \\
\hline
\end{tabular}

\begin{tabular}{|c|c|c|c|c|c|}
\hline 122 & Asn & 118.91 & 175.12 & 53.12 & 38.94 \\
\hline 123 & Glu & 121.60 & 175.82 & 56.52 & 29.73 \\
\hline 124 & Ala & 124.19 & 176.94 & 51.99 & 18.78 \\
\hline 125 & Tyr & 119.82 & 175.06 & 57.48 & 38.62 \\
\hline 126 & Glu & 123.65 & 175.15 & 55.27 & 30.37 \\
\hline 127 & Met & 123.69 & 173.96 & 52.88 & 31.96 \\
\hline 128 & Pro & 137.56 & 176.60 & 62.60 & 31.89 \\
\hline 129 & Ser & 116.62 & 174.52 & 57.95 & 63.57 \\
\hline 130 & Glu & 123.02 & 176.27 & 56.20 & 29.91 \\
\hline 131 & Glu & 121.76 & 176.66 & 56.53 & 29.89 \\
\hline 132 & Gly & 109.88 & 173.57 & 44.81 & \\
\hline 133 & Tyr & 120.13 & 175.48 & 57.78 & 38.45 \\
\hline 134 & Gln & 122.52 & 174.61 & 55.10 & 29.43 \\
\hline 135 & Asp & 121.50 & 175.23 & 53.92 & 40.84 \\
\hline 136 & Tyr & 120.29 & 174.79 & 57.25 & 38.77 \\
\hline 137 & Glu & 125.22 & 173.41 & 53.36 & 29.89 \\
\hline 138 & Pro & 136.60 & 176.58 & 62.55 & 31.84 \\
\hline 139 & Glu & 121.39 & 175.12 & 56.21 & 29.90 \\
\hline 140 & Ala & 130.73 & 182.28 & - & - \\
\hline
\end{tabular}

- Not assigned 


\section{References}

(1) Grzesiek, S.; Bax, A. J.Biomol.NMR 1997, 9, 207-211.

(2) Liu, A.; Riek, R.; Wider, G.; Von Schroetter, C.; Zahn, R.; Wüthrich, K. J.Biomol.NMR 2000, 16, 127-138.

(3) Emsley, L.; Bodenhausen, G. Chem.Phys.Lett. 1990, 165, 469-476.

(4) Boehlen, J.-M.; Bodenhausen, G. J.Magn.Reson.Ser.A 1993, 102, 293-301.

(5) Shaka, A. J.; Keeler, J.; Freeman, R. J.Magn.Reson. 1983, 53, 313-340.

(6) Shaka, A. J.; Barker, P. B.; Freeman, R. J.Magn.Reson. 1985, 64, 547-552.

(7) Nielsen, N. C.; Thøgersen, H.; Sørensen, O. W. J.Am.Chem.Soc. 1995, 117, 11365-11366.

(8) Bermel, W.; Bertini, I.; Duma, L.; Emsley, L.; Felli, I. C.; Pierattelli, R.; Vasos, P. R. Angew.Chem.Int.Ed. 2005, 44, 3089-3092.

(9) Bermel, W.; Bertini, I.; Felli, I. C.; Kümmerle, R.; Pierattelli, R. J.Magn.Reson. 2006, 178, 56-64. 